\title{
$\mathrm{M}|\mathrm{R}| \mathrm{S}$
}

A Publication of the Materials Research Society

Volume 21, Number 2 ISSN: 0883-7694 CODEN: MRSBEA

INTERATOMIC

POTENTIALS FOR ATOMISTIC SIMULATIONS

17 Interatomic Potentials for Atomistic Simulations

A.F. Voter, Guest Editor

20 Pair Potentials in Atomistic Computer Simulations

V. Vitek

24 Embedded-Atom and Related Methods for Modeling Metallic Systems S.M. Foiles

29 The Shell Model and Interatomic Potentials for Ceramics

M. Stoneham, J. Harding, and T. Harker

36 Chemical Dynamics and Bond-Order Potentials

D.W. Brenner

42 Tight-Binding Theory and Computational Materials Synthesis

A.P. Sutton, P.D. Godwin, and A.P. Horsfield

\section{MRS NEWS}

50 Preview: 1996 MRS Spring Meeting

JMR ABSTRACTS

78 Abstracts for April 1996 Journal of Materials Research

\section{DEPARTMENTS}

\section{Material Matters}

6 Advertisers in This Issue

8 Research/Researchers

13 Washington News

14 Resources

16 Editor's Choice

65 Links of Science \& Technology

Diamond Synthesis:

The Russian Connection,

R.C. DeVries, A. Badzian, and R. Roy

77 Historical Note

86 Library

86 Classified

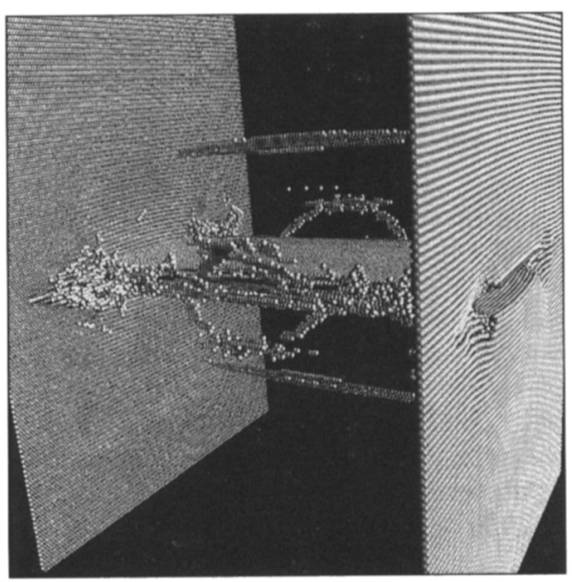

ON THE COVER: Molecular-dynamics simulation of crack blunting by dislocation emission in copper under tensile loading using a realistic, embedded-atom interatomic potential. An atomistically sharp crack (artificially prepared) becomes an elliptical cylinder as the system is strained vertically to $4.7 \%$ (rate $\left.=10^{9} \mathrm{~s}^{-1}\right)$. Atoms are visualized in order of their potential energy (perfect bulk atoms are invisible): Crack blunting dislocation loops emitted in the $\{111\}$ planes and jogging dislocations emitted at the junction of the crack front with the free surface are white and gray; the internal (001) crack surfaces are yellow; two (110) free surfaces terminating the crack are red (first subsurface layer is gray); the junction of the crack and the (110) surface is cyan. This $3.5 \times 10^{6}$-atom simulation was performed by Shujia Zhou, David Beazely, Peter Lomdahl, Brad Holian, and Art Voter of the Theoretical Division at Los Alamos National Laboratory, using the massively parallel SPaSM code on the $\mathrm{CM}-5$ in the Advanced Computing Laboratory. An introduction to interatomic potentials for atomistic simulations begins on page 17. 


\section{About the Materials Research Society}

The Materials Research Society (MRS) a nonprofit scientific association founded in 1973 promotes interdisciplinary goal-oriented basic research on materials of technological importance. Membership in the Society includes over 12,000 scientists, engineers, and research managers from industrial, government, and university research laboratories in the United States and nearly 50 countries.

The Society's interdisciplinary approach differs from that of single-discipline professional societies because it promotes information exchange across the many technical fields touching materials development. MRS sponsors two major international annual meetings encompassing approximately 60 topical symposia, and also sponsors numerous single-topic scientific meetings. The Society recognizes professional and technical excellence and fosters technical interaction in local geographic regions through Sections and University Chapters.

MRS participates in the international arena of materials research through the International Union of Materials Research Societies (IUMRS). MRS is a member of the Federation of Materials Societies and is an affiliate of the American Institute of Physics.

MRS publishes symposium proceedings, MRS Bulletin, Journal of Materials Research, and other publications related to current research activities.

MRS Bulletin (ISSN: 0883-7694) is published 12 times a year by the Materials Research Society, 9800 McKnight Road, Pittsburgh, PA 15237. Application to mail at second class rates has been approved at Pittsburgh, PA and at additional mailing offices. POSTMASTER: Send address changes to MRS Bulletin in care of the Materials Research Society, at the address listed; phone (412) 367-3003; fax (412) 367-4373. Printed in the U.S.A

Additional copies of articles in MRS Bulletin may be made at $\$ 2.50$ per article. This fee can be paid to the Materials Research Society through the Copyright Clearance Center, Inc. 27 Congress Street, Salem, MA 01970.

Membership in MRS is $\$ 75$ annually for regular members, $\$ 25$ for students. Dues include an allocation of $\$ 29$ (\$17 for students) to a subscription to MRS Bulletin. Individual member subscriptions are for personal use only. Non-member subscription rates are $\$ 135$ for one calendar year (12 issues) within the U.S.A and \$185 elsewhere. Single copies may be purchased for $\$ 16$ each. Send subscription orders to Subscrip tion Department, Materials Research Society 9800 McKnight Road, Pittsburgh, PA 15237.

MRS Bulletin is included in Current Contents ${ }^{*} /$ Engineering, Computing, and Technology Current Contents $s^{\circ} /$ Physical, Chemical and Earth Sciences, the SciSearch ${ }^{8}$ online database, Research Alert* Science Citation Index, and the Materials Science Citation Index". Back volumes of $M R S$ Bulletin are available in $16 \mathrm{~mm}$ microfilm, $35 \mathrm{~mm}$ microfilm, or $105 \mathrm{~mm}$ microfiche through University Microfilms Inc., 300 North Zeeb Road, Ann Arbor, Michigan 48106.

\section{Materials Research Society 9800 McKnight Road}

Pittsburgh, PA 15237-6006

Tel. (412) 367-3003; Fax (412) 367-4373 http://www.mrs.org/

Editorial Office • 9800 McKnight Road • Pittsburgh, PA 15237-6006

Tel. (412) 367-3004 x522; fax (412) 367-4373; http://www.mrs.org/

$\begin{array}{ll}\text { Editor } & \text { Advertising } \\ \text { E.L. Fleischer } & \text { M.E. Kaufold } \\ \text { Managing Editor } & \text { Circulation } \\ \text { J. Meiksin } & \text { S.E. Krasa } \\ \text { Assistant Editor } & \text { Guest Editor } \\ \text { L.R. Gallagher } & \text { A.F. Voter } \\ \text { Art Director } & \text { Special Contributors } \\ \text { C. Love } & \text { l. Amato, P.F. Becher, } \\ \text { Design/Production } & \text { L.A. Krysinski, E. Pennisi, } \\ \text { T. Aiello and S. Franklin } & \text { and R.S. Walker } \\ \text { Editorial Assistants } & \text { Special Consultant } \\ \text { M.M. Costello and J. Dininny } & \text { M. Goodway }\end{array}$

\author{
Associate Editor-Europe \\ I.W. Boyd \\ University College London \\ Dept. of Electronic and \\ Electrical Engineering \\ Torrington Place \\ London WCI E7 JE, U.K
}

Tel. 44-171-380-7300 or 7302

Book Review Editor

C.J. McHargue

University of Tennessee

Knoxville, Tennessee

MRS Office of Public Affairs

55513 th Street NW, Suite 900 East

Washington, DC 20004

Tel. (202) 383-8809, Fax (202) 383-8877

CHAIR-EDITORIAL BOARDS

E.N. Kaufmann • Argonne National Laboratory • Argonne, Illinois, USA

\title{
INTERNATIONALADVISORY BOARD
}

M. Balkanski

University of Pierre and Marie Curie

Paris, France

R.G. Elliman

Australian National University

Canberra, Australia

S. Hsu

Chung Shan Institute of Science

and Technology, Retired

Taiwan, China

\section{TECHNICAL EDITORIAL BOARD}

\section{J.C. Bravman}

Stanford University

Stanford, California, USA

C.W. Draper

AT\&T Engineering Research Center

Princeton, New Jersey, USA

E. Fogarassy

Centre de Recherches Nucléaires

Strasbourg, France

L.C. lanniello

U.S. Department of Energy, Retired

Washington, DC, USA

H-D. Li

National Science Foundation-China

Beijing, China

P. Rama Rao

Ministry of Science and Technology

New Delhi, India

F.Y. Fradin

Aroonne National Laboratory

Argonne, Illinois, USA

B.M. León

Universidad de Vigo

Vigo, Spain

G.L. Liedl

Purdue University

West Lafayette, Indiana, USA
R. Roy

The Pennsylvania State University University Park, Pennsylvania, USA

T. Sugano

Toyo University

Tokyo, Japan

D.L. Weaire

University of Dublin

Dublin, Ireland

MRS BULLETIN PUBLICATIONS SUBCOMMITTEE

M. Nastasi, Chair

Los Alamos National Laboratory

Los Alamos, New Mexico

R.C. Ewing

University of New Mexico

Albuquerque, New Mexico

R.L. Fleischer

Rensselaer Polytechnic Institute

Troy, New York

\section{A.J. Hurd}

Sandia National Laboratories

Albuquerque, New Mexico

M. Libera

Stevens Institute of Technology

Hoboken, New Jersey
S. Namba

Nagasaki Institute of Applied Science

Tokyo, Japan

A.D. Romig Jr.

Sandia National Laboratories

Albuquerque, New Mexico, USA

J. Soares

Universidade de Lisboa

Lisboa, Portugal

K.C. Taylor

General Motors R\&D Center

Warren, Michigan, USA

F. Shapiro

Drexel University

Philadelphia, Pennsylvania

C.W. White

Oak Ridge National Laboratory

Oak Ridge, Tennessee

\section{MRS EXECUTIVE COMMITTEE \\ 1996 MRS EXECUTHE COMMITTEE}

\section{President}

C.V. Thompson

Massachusetts institute of Technology

First Vice President and President-Elect

R. Hull

University of Virginia

Second Vice President and

Vice President-Elect

R.J. Nemanich

North Carolina State University

Secretary

K.S. Jones

University of Florida

Treasurer

A.K. Hays

Sandia National Laboratories

Immediate Past President

J.M. Phillips

Sandia National Laboratories
Councillors

R. Gibala

University of Michigan

A.I. Taub

Ford Research Laboratory

Executive Director

Materials Research Society

John B. Ballance

\section{INTERNATIONAL UNION OF MATERIALS RESEARCH SOCIETIES}

President

M. Doyama

Nishi-Tokyo University

Tokyo, Japan
Vice President

R.C. Ewing

University of New Mexico

Albuquerque, New Mexico

USA
Treasurer

G.M. Crean

Secretary

National Central University

Chung-Li, Taiwan
University College

Cort, Ireland
Immediate Past President

P. Siffert

Centre de Recherches Nucléaires

Strasbourg, France
General Secretary

R.P.H. Chan

Northwestern University

Evanston, Illinois

USA

IUMRS ADHERING BODIES

Australian Materials Research Society (A-MRS)

J.S. Williams, Austalian National University

Chinese Materials Research Society (C-MRS)

$\mathrm{H}-\mathrm{D}$. Li, National Science Foundation-China

European Materials Research Society (E-MRS)

P.A. Glasow, Siemens AG

Materials Research Society of India (MRS-I)

P. Rama Rao, Technology Bhavan

Materials Research Society of Japan (MRS-J)

T. Takagi, Ion Engineering Research Institute Corp.

Materials Research Society of Korea (MRS-Korea)

J-T. Song, Hanyang University
Materials Research Society of Russia (MRS-Russia)

I.V. Gorynin, Prometey Institute

Materials Research Society of Taiwan (MRS-T)

L.J. Chen, National Tsing Hua University

Mexican Materials Research Society (Mexican-MRS)

L.M. Gomez, Instituto de Fisica-Cuernavaca, UNAM 